\title{
Growth rates of Rhizocarpon geographicum lichens: A review with new data from Iceland
}

\author{
TOM BRADWELL \\ British Geological Survey, West Mains Road, Edinburgh EH9 3LA, UK \\ Email: tbrad@bgs.ac.uk Tel: 01316500284 Fax:01316681535 \\ Richard A. ARMStrong \\ Vision Sciences, Aston University, Birmingham B4 7ET, UK
}

\begin{abstract}
This article reviews evidence from previous growth-rate studies on lichens of the yellowgreen species of Subgenus Rhizocarpon - the family most commonly used in lichenometric dating. New data are presented from Rhizocarpon section Rhizocarpon thalli growing on a moraine in southern Iceland over a period of 4.33 years. Measurements of 38 lichen thalli, between 2001 and 2005, show that diametral growth rate (DGR, mm $\mathrm{yr}^{-1}$ ) is a function of thallus size. Growth rates increase rapidly in small thalli ( $<10 \mathrm{~mm}$ diameter), remain high (c. $0.8 \mathrm{~mm} / \mathrm{yr}$ ) and then decrease gradually in larger thalli ( $>50 \mathrm{~mm}$ diameter). Mean DGR in southern Iceland, between 2001 and 2005, was $0.64 \mathrm{~mm} \mathrm{yr}^{-1}$ (SD = 0.24). The resultant growth-rate curve is parabolic and is best described by a third-order polynomial function. The striking similarity between these findings in Iceland and those of Armstrong (1983) in Wales implies that the shape of the growth-rate curve may be characteristic of Rhizocarpon geographicum lichens. The difference between the absolute growth rate in southern Iceland and Wales (c. 66\% faster) is probably a function of climate and micro-environment between the two sites. These findings have implications for previous lichenometric-dating studies; namely, that those studies which assume constant lichen growth rates over many decades are probably unreliable.
\end{abstract}

Key words: lichenometry, Rhizocarpon section Rhizocarpon, climate, dating 


\section{Introduction}

Lichens are valuable dating tools for geoscientists. The combination of extremely slow growth in certain crustose species and their wide distribution in nature have been key factors in most lichenometric dating studies. Knowledge of a species' growth rate can be used to estimate the age of the surface on which they are growing, assuming that lichen colonisation occurs immediately after exposure. Lichenometric-dating studies have been performed by numerous workers to answer a wide range of geochronological questions since the technique was pioneered by Beschel in 1950 (Table 1). Most lichenometric-dating studies have focused on the yellow-green species of Rhizocarpon, more precisely known as Rhizocarpon Ram. em. Th. Fr. subgenus Rhizocarpon (Poelt, 1988).

Despite the numerous dating studies that have utilised the growth rate of crustose lichens (Table 1), few attempts have been made to analyse the actual growth mechanisms or to study the growth history of a Rhizocarpon lichen thallus. Such a relatively poor understanding has led to considerable controversy regarding the use of lichenometry, particularly amongst biologists. Given the current popularity of lichenometric-dating studies in the earth sciences (eg. Noller and Locke, 2001; McCarthy, 2003; Solomina and Calkin, 2003; Lowell et al., 2005, Matthews, 2005), a review of measured lichen-growth rates within the Rhizocarpon species seems timely. In addition, we present new data from Iceland regarding the growth curve of Rhizocarpon geographicum.

\section{Review of previous growth-rate studies}

The direct method

Twelve articles have reported growth data measured over a period of 12 months or more for species within the Rhizocarpon subgenus:- Hausmann (1948), Ten Brink (1973), Hooker (1980), Armstrong (1983), Proctor (1983), Rogerson et al., (1986), Haworth et al., (1986), Matthews (1994), Winchester \& Chaujar (2002), McCarthy (2003), Sancho and Pintado (2004) and Armstrong (2005). With the exception of Matthews' and McCarthy's studies, all the measurements refer to thalli of 'Rhizocarpon geographicum'. 
Ethel Hausmann (1948) was probably the first to publish information regarding the growth rate of Rhizocarpon geographicum. Her observations of a single $R$. geographicum 'map lichen' growing near the summit of Mt. Monadnock, New Hampshire, showed that the growth rate of $R$. geographicum over a four-year period

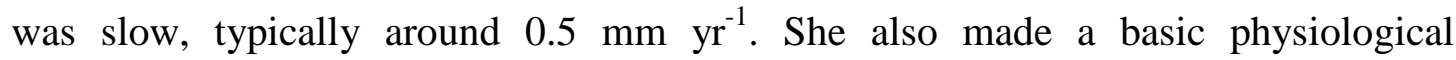
assumption that the rock-lichens in question grew fastest in the wettest year when the mountain was "more swathed in clouds” than normal.

Roland Beschel (1956, 1961) measured and photographed Rhizocarpon lichens in west Greenland. Ten Brink (1973) revisited Beschel's control sites and determined the growth rate of several Rhizocarpon geographicum thalli over the intervening 12-year period using the photogrammetric method. The results show that growth rates had

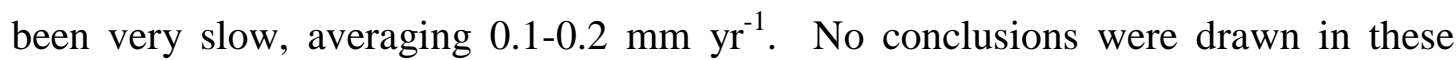
studies regarding the growth history of the plants.

Antarctic crustose lichens are presumed to be amongst the slowest-growing and, hence, longest-living organisms on Earth. Hooker's photogrammetric studies on the South Orkney Islands between 1972 and 1977 were published in 1980. He detected no measurable growth during a 2.5-year period in any of the 63 Rhizocarpon geographicum thalli being monitored. However, after a subsequent three-year period, small amounts of radial growth were recorded, optimally around $0.1 \mathrm{~mm} \mathrm{yr}^{-1}$. Using this data he estimated average radial growth rates in the maritime sub-Antarctic to be of the order of $4 \mathrm{~mm} 100 \mathrm{yr}^{-1}$. Hooker (1980) was unable to demonstrate any significant effect of thallus size on growth rate.

Armstrong's (1983) observations on the growth of Rhizocarpon geographicum in North Wales comprise the first major study of the growth curve of a crustose lichen. He measured the radial growth of 39 thalli over a period of 1.5 years, using a graduated scale under high magnification. Armstrong's results detected three distinct phases of growth - an initial phase where radial growth rates increased rapidly, a second phase where radial growth rates are high and relatively constant, and a declining phase where growth rates fell. The statistical representation of this growth rate decline has been questioned (Innes, 1985). However, the growth rate of each of the thalli over $55 \mathrm{~mm}$ in diameter falls below the mean growth rate of thalli between 
15 and $55 \mathrm{~mm}$ in diameter. Armstrong's evidence suggested that a phase of declining growth occurs in thalli over $\sim 50 \mathrm{~mm}$ in diameter and hence that growth is a size (age) dependent phenomenon in Rhizocarpon geographicum.

Proctor (1983) studied the growth rate of thalli growing on the moraines of an Alpine glacier in Switzerland. He took photographs of numerous sites at four-year intervals and using these, calculated the radial growth rate of 22 Rhizocarpon geographicum thalli. He then constructed a curve of mean radial growth increment against thallus radius showing that smaller thalli $(<10 \mathrm{~mm})$ grew significantly more slowly than larger thalli. Unfortunately, Proctor's dataset does not include any thalli of more than $36 \mathrm{~mm}$ in diameter. In addition, Proctor assumed constant growth rates in thalli over $\sim 10 \mathrm{~mm}$ in diameter and extrapolated the linear part of his growth curve for thalli up to $60 \mathrm{~mm}$ in diameter, without any further measurements. The statement then made regarding the growth curve of Rhizocarpon geographicum would seem to be overoptimistic, viz., "That lichen thalli can grow with a near-constant radial increment for periods of many years is now established beyond question” (1983: 258).

Rogerson et al. (1986) photographed and measured 7 thalli of Rhizocarpon section Rhizocarpon geographicum growing on rocks in the coastal mountains of northern Labrador in 1978 and again in 1983. Diameter increases of $0.10-0.58 \mathrm{~mm} \mathrm{yr}^{-1}$ were derived using the photogrammetric method of Locke et al. (1979). They reported an average diameter increase of $0.34 \mathrm{~mm} \mathrm{yr}^{-1}$ over the five-year period, with a range from 0.10 to $0.54 \mathrm{~mm} \mathrm{yr}^{-1}$. Due to the small number of thalli measured, including only two greater than $50 \mathrm{~mm}$ in diameter, their study sheds little new light on the relationship between thallus size and growth rate.

Haworth et al. (1986) measured 92 Rhizocarpon geographicum 'sensu lato' thalli over a 4-6-year period in the Central Brooks Range, Alaska. They determined mean annual change in diameter using a combination of photogrammetric and tracing techniques. Diametral growth rates ranged from 0 to $0.35 \mathrm{~mm} \mathrm{yr}^{-1}$ with variability being high within and between sites. Their study, like Armstrong's (1983), also found evidence, though poorly defined, for an inverse relationship between thallus growth rate and thallus size. The authors reached the following conclusion (1986: 294):

"The growth curve developed for Rhizocarpon geographicum shows 
continuously slowing increases in diameter throughout the life of the thallus."

Haworth et al., (1986) also stated that lichen age was only one of many factors contributing to variations in growth rate, along with substrate lithology, micro-climate and competition between thalli.

Matthews (1994) presented direct measurements of 63 thalli of the Rhizocarpon subgenus (probably only species within sections Rhizocarpon and Alpicola, (Matthews, pers. comm. 2000)). His measurements were conducted over a five-year period on the outermost moraine at Nigardsbreen, southern Norway. Dial callipers were used to measure the long axes of only well-defined thalli. Matthews found no indication of a decline in growth rate with increasing thallus size. However, the extreme scatter within the dataset precludes the identification of any possible trends. Furthermore, the use of an "aggregate species" may cause any growth rate decline in Rhizocarpon geographicum to be obscured amongst data from species within different lichen groups (i.e. Rhizocarpon alpicola; (see Innes, 1983; 1985)). The reported linear growth rate in Rhizocarpon thalli up to $120 \mathrm{~mm}$ in diameter should therefore be viewed with caution.

Winchester and Chaujar (2002) measured Rhizocarpon geographicum lichens on gravestones in North Wales, as part of a lichenometric study on mass movement deposits. Measurements were made with a flexible tape accurate to $\pm 1 \mathrm{~mm}$. They recorded thallus diameter increases from 2 to $11 \mathrm{~mm}$ over a 4.25 yr period, with an average of $1.47 \mathrm{~mm} \mathrm{yr}^{-1}$. Winchester and Chaujar (2002) found no relationship between thallus size and growth rate. However, their study of 32 lichens only included two below $20 \mathrm{~mm}$ in diameter, and also combined data from two sites $8 \mathrm{~km}$ apart.

McCarthy (2003) has provided the largest dataset on Rhizocarpon growth rates to date. 105 Rhizocarpon section Rhizocarpon thalli, ranging from 5-50 mm in diameter, were measured at annual intervals over a four-year period. (McCarthy states that most of the 105 thalli belonged to the species Rhizocarpon lecanorinum Anders.) The lichens were growing on boulders on a moraine crest in front of the Illecillewaet Glacier, British Columbia. Measurements were made using digital calipers accurate to 
$\pm 0.02 \mathrm{~mm}$. His measurements showed that mean radial growth rates, between 1996 and 2000, ranged from 0.26 to $0.41 \mathrm{~mm} \mathrm{yr}^{-1}$. However, there was considerable scatter around the mean in every year (range $=\sim 1.0 \mathrm{~mm} \mathrm{yr}^{-1}$ ). McCarthy found that thallus size was a poor predictor of thallus growth rate. Only weak positive correlations $\left(\mathrm{r}^{2}<\right.$ 0.3) were found between radial growth and thallus diameter. However, it should be remembered that all but 2 of the thalli were under $45 \mathrm{~mm}$ in diameter in McCarthy's dataset, and none was over $50 \mathrm{~mm}$ in diameter. Consequently, any growth-rate decline in large thalli (>50 mm), as suggested by Armstrong (1983), is unlikely to have been detected in McCarthy's (2003) study.

Leopoldo Sancho measured and photographed Rhizocarpon geographicum (L). DC. thalli in 1991 on Livingston Island in the maritime Antarctic. Revisiting the same boulders on moraines in 2002 he was able to calculate the diametral growth rate of around 400 crustose lichens over 11 years, including 100 Rhizocarpon geographicum (Sancho and Pintado, 2004). Measurments were made with digital calipers accurate to $\pm 0.1 \mathrm{~mm}$. This study deduced mean growth of $0.50 \mathrm{~mm} \mathrm{yr}^{-1}$ for the five largest thalli between 1991 and 2002. Unfortunately, the diameters of the thalli were not included in the results table making it difficult to draw conclusions about the role of lichen size on growth rate. However, all the Rhizocarpon lichens in the study were less than $20 \mathrm{~mm}$ in diameter (Sancho and Pintado, 2004). Interestingly, this study highlights faster than expected growth rates in a maritime, subantarctic environment.

Most recently, Armstrong (2005) measured the growth of 39 yellow-green Rhizocarpon section Rhizocarpon lichens on boulders in the Cascade Mountains of Washington State, USA. Measurements were made between 1988 and 1994 using a micrometer scale under x8 magnification. His study found slow radial growth rates in this high-altitude montane environment (typically c. $0.1 \mathrm{~mm} \mathrm{yr}^{-1}$ ), probably as a direct result of the short snow-free periods experienced. In this environment, Armstrong found no relationship between lichen size and growth rate, which may have been masked by the slow growth rates recorded during the 6-yr study (Armstrong, 2005). 


\section{The Indirect method}

Earth scientists interested in dating recently exposed rock surfaces have contributed valuable information on lichen growth rates. Measuring the size of lichen thalli on surfaces of known age offers a method of studying the growth rates of slow-growing lichens over periods of many decades. The majority of workers have derived nonlinear dating curves using Rhizocarpon species (eg. Beschel, 1958, 1961; Miller, 1969; Miller and Andrews, 1972; Mottershead and White, 1972; Denton and Karlén, 1973; Matthews, 1974; Innes, 1985; Benedict, 1985; Bull and Brandon, 1998; Bradwell, 2001a; Solomina and Calkin, 2003; Larocque and Smith, 2004; Lowell et al., 2004). These age-size curves provide indirect evidence that lichen growth slows with time, possibly as a function of thallus size. Those workers who report a linear relationship between exposure age and lichen size, using Rhizocarpon lichens, have probably identified only part of a larger curve or have extrapolated growth rates without justification (eg. Burrows, 1975; Gordon and Sharp, 1983; Maizels and Dugmore, 1985; Kugelmann, 1991; Evans et al., 1999; Kirkbride and Dugmore, 2001).

Two recent indirect growth-rate studies should be discussed at this point. Karlén and Black (2002) revisited surfaces hosting Rhizocarpon geographicum lichens, originally measured by Karlén in 1970-71 (Karlén, 1973). Lichen measurements were conducted in the year 2000 on "close to identical surfaces" as those used in 1970 . The results indicate that growth rates were apparently similar in large and small thalli. Karlén and Black (2002) found diameter increases in lichens on 14 surfaces equivalent to

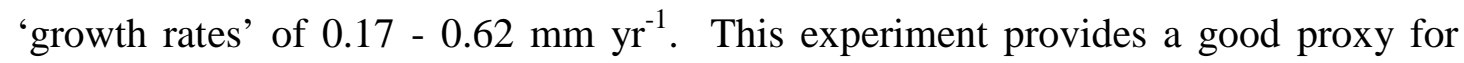
lichen growth rates over the intervening 30 years. However, the measurements were not made on exactly the same thalli and therefore are not actual, directly measured, lichen growth rates. Karlén and Black (2002: 229) also stated that the "maximum lichen diameter may have been underestimated in 2000" due to snow restricting the observable area. Furthermore, the inclusion of lichens from other sections within the subgenus (including R. alpicola) could not be ruled out.

A second recent study by O’Neal and Schoenenberger (2003) revisited surfaces in the Cascade Mountains hosting Rhizocarpon geographicum, originally measured by Porter (1981). They constructed a growth curve from repeated measurements of 
'largest lichens' diameters at three sites: Mt Hood, Mt Rainier and Mt Baker. The resultant growth curve was curvilinear, implying increasing, then constant, then decreasing growth rates. Interestingly, the implied decrease in growth rate occurred in thalli $>60 \mathrm{~mm}$ in diameter. When the role of thallus size on growth rate over the $\sim 25$ year period is examined, lichens $<40 \mathrm{~mm}$ in diameter appeared to grow at c. $0.5 \mathrm{~mm}$ $\mathrm{yr}^{-1}$; whilst the largest lichens ( $>50 \mathrm{~mm}$ ) increased in diameter by only c. $0.25 \mathrm{~mm} \mathrm{yr}^{-1}$.

\section{New growth rate data from Iceland}

A direct study of lichen growth rates was conducted on the terminal moraine complex at Gigjökull, southern Iceland, over a 4.33-year period between May 2001 and September 2005.

\section{Study site}

Gigjökull is a steep glacier flowing from the summit of the ice-capped Eyjafjöll volcano. Parts of the Eyjafjalljökull ice cap receive in excess of $4000 \mathrm{~mm}$ precipitation a year, although the valleys and outwash plains to the north and east experience considerably less (<2500 mm yr)(Figure 1; B). Rainfall data from Basar, $10 \mathrm{~km}$ east of Gigjökull, records an annual mean of $2350 \mathrm{~mm} \mathrm{yr}^{-1}$ (between 19912001). The study site experiences a mean annual temperature of c. $3^{\circ} \mathrm{C}$, and a mean annual temperature range of $11^{\circ} \mathrm{C}$ (Einarson, 1991) (Figure 1, B).

Four, large, porphyritic basalt, boulders were selected: two near the base of the ice-proximal slope and two on the broad crest of the terminal moraine, $300 \mathrm{~m}$ away. These are referred to as measurement stations 1 and 2, respectively (Figure 1, C). Yellow-green Rhizocarpon lichens were selected for measurement on gently sloping north and west-facing boulder surfaces. Lichens on horizontal surfaces or in small depressions were avoided, as these could act as collection points for rainwater. The area is free from human disturbance, has no trees and is $300 \mathrm{~m}$ from the nearest stream. Hence, all thalli are thought to share the same microclimatic conditions.

\section{Methods}

41 non-competing, approximately circular, Rhizocarpon section Rhizocarpon thalli were marked and photographed in early May 2001. All lichens had sharp margins with clearly defined hypothalli. All thalli were identified in the field, using the criteria 
of Poelt (1988), as Rhizocarpon section Rhizocarpon (formerly the Geographicum group of Runemark (1956)). Although chemical identification to species level was not undertaken in Iceland, all 41 thalli were examined using a x8 handlens against the broadly circumscribed criteria of Purvis et al. (1992); most could be identified as Rhizocarpon geographicum (L.) DC. Furthermore, each thalli was examined to ensure that it did not comprise two or more intergrown individuals. Identification marks were made with white oil-based paint and Rotring pen, several millimetres away from the edge of the thallus margin (as done by Benedict, 1988; McCarthy, 2003). Each lichen was numbered - GIG01 to GIG41. Measurements of thallus diameter, longest axis and 90 degrees to the longest axis, were made in the field using a clear flexible rule with $0.1 \mathrm{~mm}$ graduations and x8 handlens (Figure 2, A). Measurement precision using this technique is probably only $\pm 0.5 \mathrm{~mm}$, particularly on larger thalli and rough surfaces. All measurements were made by the same operator. Photographs were taken with a Canon EOS 35mm camera on Fujicolour slide film. The distance from lichen to camera was kept below $10 \mathrm{~cm}$ using a Sigma macro lens to minimise photographic distortion. The lichens were re-photographed and remeasured in September 2005. Slide photographs from 2001 and 2005 were scanned using a Sony film scanner UYS100. To obtain more precise measurements of lichen growth, the images were enlarged 400\% in Adobe Photoshop and accurately overlaid, using the identification marks as reference points. Minor corrections were made for geometric distortion using the method outlined by Locke et al. (1979). Tracings of the thallus margin in 2001 and 2005 allowed the lichen growth to be visualised and quantified. On-screen measurements of thallus diameter, longest axis and 90 degrees to the longest axis, were made for all thalli from photographs taken in 2001 and 2005 (Figure 2, B). Using this photogrammetic technique, measurement precision increases to $\pm 0.05 \mathrm{~mm}$.

\section{Results}

38 of the lichens showed measurable growth over the study period. Two thalli could not be positively identified in 2005; one had died and disintegrated. The diametral growth rate (DGR) of 38 individual thalli was calculated assuming constant growth throughout the 4.33-year period (ie. total diameter increase divided by 52 months) and expressed in $\mathrm{mm}^{-1}{ }^{-1}$. The average maximum growth rate of each lichen thallus has been plotted against its respective maximum diameter in May 2001 (Figure 3). The 
resultant graph shows DGR between thalli varies from $0.23 \mathrm{~mm}$ to $1.39 \mathrm{~mm} \mathrm{yr}^{-1}$; the mean DGR in the 38 thalli being $0.65 \mathrm{~mm} \mathrm{yr}^{-1}$. The range (1.16) and standard deviation of the dataset $(0.24)$ reveal a moderate degree of scatter around the mean.

The data reveal a distinct relationship between thallus size and DGR in Rhizocarpon geographicum, with growth appearing to be most rapid in 10-40 mm diameter thalli. Whilst slower DGR were recorded in the smallest thalli ( $<10 \mathrm{~mm}$ in diameter) and in the largest thalli ( $>50 \mathrm{~mm}$ in diameter). The shape of the growth-rate curve is optimally described $\left(r^{2}=0.44\right)$ by a third-order polynomial curve, initially accelerating to a peak around $30 \mathrm{~mm}$ before gradually declining, possibly in an asymptotic way. Linear regression $\left(r^{2}=0.004\right)$ and a second-order polynomial $\left(r^{2}=\right.$ 0.34) yield weaker best-fit values. The evidence for slower radial growth in the smallest thalli is clear, as all 7 thalli $<10 \mathrm{~mm}$ in diameter have DGR less than the average of the whole dataset. The evidence for slower growth in large thalli is also clear with 9 out of the 10 largest thalli ( $>40 \mathrm{~mm}$ ) having DGR less than the mean of the whole dataset. The mean DGR of lichens in the $40-80 \mathrm{~mm}$ size range is $30 \%$ less than the mean DGR of those in the $10-40 \mathrm{~mm}$ size range $\left(0.54 \mathrm{~mm} \mathrm{yr}^{-1} \mathrm{cf} .0 .78 \mathrm{~mm}\right.$ $\mathrm{yr}^{-1}$ ). Furthermore, three of the four largest lichens, all $>60 \mathrm{~mm}$ in diameter, have growth rates of $<0.45 \mathrm{~mm} \mathrm{yr}^{-1}$; which is appreciably slower than those thalli in the 10 $40 \mathrm{~mm}$ size range.

\section{Discussion}

The new growth study described above was set up in 2001, following lichenometric investigations by one of the authors in southern Iceland (Bradwell, 2001a, 2004, Bradwell et al., 2006), to determine whether the growth rate of Rhizocarpon lichens was linear over time or a function of thallus size. Previous direct-measurement studies have revealed considerable uncertainty over the exact shape of the growth curve of Rhizocarpon geographicum, with some studies suggesting that growth rates decline in larger thalli (Armstrong, 1983; Haworth et al, 1986), whilst others found no evidence of this decline (Matthews, 1994; Winchester and Chaujar, 2002).

The present study suggests that in south Iceland Rhizocarpon geographicum thalli conform to a parabolic growth-rate curve. The steep rising limb corresponds to accelerating DGR in small, younger thalli; the crest of the curve corresponds to the 
period of maximum DGR; and the slowly declining phase represents a growth rate decline in larger, older thalli. This model of growth fits well with indirect lichen growth-rate studies that predict accelerating growth, followed by rapid, then exponentially decreasing growth (eg. Matthews, 1975; Thompson and Jones, 1986; Bradwell, 2001a; O’Neal and Schoenenberger, 2002; Larocque and Smith, 2004).

The new data from Iceland can be compared with the results of a similar study carried out in north Wales almost 25 years ago (Armstrong, 1983). Armstrong's dataset (1983) involved 40 lichen thalli of $R$. geographicum, ranging in size from $3-65 \mathrm{~mm}$, measured over an 18-month period. The trend was best described by a third-order polynomial function $\left(r^{2}=0.48\right)$. The similarity between the growth-rate curve of Armstrong's dataset (1983) and the present study is striking (Figure 4). (Armstrong’s dataset has been normalised to show growth rates over a 12-month period). Both curves display an increasing growth phase, followed by a maximum at $\sim 30 \mathrm{~mm}$ and a more gentle declining phase. The coincidence of the maxima and the overall shape of the curves implies strongly similar growth curves in the two contrasting environments. The growth curves can be broadly divided into four phases of growth: an initial phase of lichen establishment; followed by increasing growth rates in the juvenile phase; relatively rapid, constant growth rates during maturation; and declining growth rates during maturity/senescense (Armstrong, 1974; Bradwell, 2001b) (Figure 5; a-d).

Naturally, the absolute growth rates at the two sites differ markedly. This difference in lichen growth rate is highly significant, being 66\% greater at the maximum in north Wales than southern Iceland. Faster average growth rates in north Wales are likely to be attributable to environmental conditions being more favourable to growth at temperate latitudes - consistent with the results of other workers (eg. Beschel, 1950, 1961; Rydzak, 1961; Armstrong, 1973; Benedict, 1990). In particular, the combination of a longer snow-free growing season (Benedict, 1990), higher frequency of rain days (Lawrey and Hale, 1977), and warmer average daytime temperatures (Kershaw, 1985) in north Wales will all tend to promote faster growth than in Iceland.

We propose that the form of the growth curve identified in the present study, together with the study of Armstrong (1983), and supported by lichenometric studies 
conducted on five continents, is characteristic of this lichen species (and possibly subgenus). The shape of this growth-rate curve has wider implications; firstly for the growth of Rhizocarpon geographicum in other climatic zones, and secondly for the use of lichens as a dating tool.

In more arid regions, where environmental conditions are not conducive to rapid growth, meangrowth rates may be relatively low, thus flattening the growth curve (Figure 5; curve 4). Where growth is extremely slow (DGR $<0.2 \mathrm{~mm} \mathrm{yr}^{-1}$ ), such as in parts of Greenland and Antarctica (Ten Brink, 1973; Hooker, 1980), the growth curve would be almost completely flat, thus effectively obscuring the 3 stages (Figure 5; curve 5). In sharp contrast, where mean $R$. geographicum growth rates are particularly rapid (DGR $>1.5 \mathrm{~mm} \mathrm{yr}^{-1}$ ), for example in parts of maritime western Europe, New Zealand and South America, the curve would be 'stretched', emphasising the parabolic nature of lichen growth (Figure 5; curve 1).

Lichenometric studies that report a linear relationship between lichen age and lichen size in Rhizocarpon lichens over many decades should be viewed with caution. The overwhelming majority of lichenometric, and some lichenological, studies find the age-size relationship to be non-linear, slowing with time. Hence, studies that report a linear relationship may have identified only part of a larger curve or may have extrapolated growth rates without justification. In the latter cases, serious doubt should be placed on the estimated lichenometric ages reported.

\section{Conclusions}

Thirteen studies have now reported directly measured growth rates of lichens in the Rhizocarpon subgenus. Of these, ten studies have examined the role of thallus size on growth rates. Three of these studies (Armstrong, 1983; Haworth et al., 1986; Bradwell and Armstrong, this study) show evidence for a decline in the growth rate of large thalli; whilst three do not include large thalli (>50 mm) (Proctor, 1983; McCarthy, 2003; Sancho and Pintado, 2004); one is inconclusive owing to the size of the dataset (Rogerson et al., 1986); and a further three studies show no evidence for a growth-rate decline (Matthews, 1994; Winchester and Shaujar, 2002; Armstrong, 2005), although Matthews (1994) used an aggregate Rhizocarpon 'species'; and Armstrong (2005) recorded very slow growth rates. Both of these factors are likely to obscure growthrate trends. On balance, these direct studies suggest that larger Rhizocarpon 
geographicum thalli grow more slowly than smaller thalli (excluding the smallest thalli $<10 \mathrm{~mm}$ ). In addition, new data (this study) suggests initially increasing then gradually decreasing growth rates, probably describing an asymptotic curve with a long tail.

The striking similarity between these new data from Iceland and those of Armstrong (1983) in Wales implies that the shape of the growth-rate curve of Rhizocarpon geographicum is probably characteristic of this species (and possibly subgenus). The difference between the absolute growth rates is probably a function of climate and microenvironment between the two sites. We find that, at its optimum, the same species grows $\sim 66 \%$ more rapidly in a more oceanic climate - probably as a result of the higher frequency of rain days and longer growing season in north Wales than in southern Iceland. This study highlights the need for correction factors when using lichen-growth curves across different climatic regions.

Finally, indirect lichenometric studies lend further support for a growth rate decline in larger thalli. A consensus finds a non-linear relationship between lichen size and age. Hence, those studies that assume a constant relationship between lichen growth and time over many decades are probably unreliable. However, indirect studies still leave question marks surrounding the role played by climatic change and the effects of ecological competition. Further long-term direct observations are required from different climatic regions to show, beyond reasonable doubt, that age is the primary control on the growth rate of lichens within the Rhizocarpon family.

\section{Acknowledgements}

We thank John Matthews, Nick Golledge, Phil Wilby and an anonymous reviewer for constructive comments on the manuscript. TB publishes with the permission of the Executive Director, BGS (NERC). 


\section{References}

André MF. 1985. Lichénométrie et vitesses d'evolution des versants arctiques pendant l'holocène (Région de la Baie du Roi, Spitsberg, $79^{\circ} \mathrm{N}$ ). Revue de Géomorphologie Dynamique 34: 49-72.

André MF. 1986. Dating slope deposits and estimating rates of rock wall retreat in Northwest Spitsbergen by lichenometry. Geografiska Annaler 68A: 65-75.

Armstrong RA. 1973. Seasonal growth and growth rate-colony size relationships in six species of saxicolous lichens. New Phytologist 72: 1023-1030.

Armstrong RA. 1974. Growth phases in the life of a lichen thallus. New Phytologist 73: 913-918.

Armstrong RA. 1983. Growth curve of the lichen Rhizocarpon geographicum. New Phytologist 73: 913-918.

Armstrong RA. 2005. Growth rate measurements of Rhizocarpon geographicum in the Snoqualmie Pass, Washington, USA. Arctic, Antarctic and Alpine Research 37: 411-415.

Ballantyne CK. 1990. The Holocene glacial history of Lyngshalvøya, northern Norway: chronology and climatic implications. Boreas 19: 93-117.

Benedict JB. 1985. Arapaho Pass: Glacial geology and archaeology at the crest of the Colorado Front Range. Center for Mountain Archaeology, Ward, Colorado, Research Reports 3:1-197.

Benedict JB. 1988. Techniques in lichenometry: identifying the yellow Rhizocarpons. Arctic and Alpine Research 20: 285-291.

Benedict JB. 1990. Experiments on lichen growth. I. Seasonal patterns and environmental controls. Arctic and Alpine Research 22: 244-254.

Benedict JB. 1993. A 2000-year lichen-snowkill chronology for the Colorado Front Range, USA. The Holocene 3: 27-33.

Beschel RE. 1950. Flechten als Altersmassstab rezenter Moränen. Zeitschrift fur Gletscherkunde und Glazialgeologie 1: 152-161.

Beschel RE. 1956. Lichenometrie im Gletschervorfeld. Jahrbuch 1957, Ver. zum Schutze der Alpenpflanzen und Tiere, Munchen 22: 164-185.

Beschel RE. 1958. Lichenometrical studies in West Greenland. Arctic 11: 254.

Beschel RE. 1961. Dating rock surfaces by lichen growth and its application to glaciology and physiography (lichenometry). In Geology of the Arctic (Proceeding of the First International Symposium on Arctic Geology), Vol. 2, Raasch G. (ed.). University of Toronto Press: Toronto; 1044-1062. 
Bickerton RW, Matthews JA. 1992. On the accuracy of lichenometric dates: An assessment based on the 'Little Ice Age' moraine sequence at Nigardsbreen, southern Norway. The Holocene 2: 227-237.

Bradwell T. 2001a. A new lichenometric dating curve for southeast Iceland. Geografiska Annaler 93A: 91-101.

Bradwell T. 2001b. Glacier fluctuations, lichenometry and climatic change in Iceland. Unpublished PhD thesis, University of Edinburgh: 365pp.

Bradwell T. 2004. Lichenometric dating in southeast Iceland: the size-frequency approach. Geografiska Annaler, 86A: 31-41.

Bradwell T, Dugmore AJ, Sugden DE. 2006. The Little Ice Age glacier maximum in Iceland and the North Atlantic Oscillation: evidence from Lambatungnajokull, southeast Iceland. Boreas 35: 61-80.

Broadbent ND, Berqvist KI. 1986. Lichenometric chronology and archaeological features on raised beaches: preliminary results from the Swedish north Bothnian coastal region. Arctic and Alpine Research 18: 297-306.

Bull WB. 1996. Dating San Andreas Fault earthquakes with lichenometry. Geology 24: 111-114.

Bull WB, Brandon MT. 1998. Lichen dating of earthquake-generated regional rockfall events, Southern Alps, New Zealand. GSA Bulletin 110: 60-84.

Bull WB, King J, Kong F, Moutoux T, Phillips, WM. 1994. Lichen dating of coseismic landslide hazards in alpine mountains. Geomorphology 10: 253-264.

Burga CA, Frauenfelder R, Ruffet J, Hoelzle M, Kääb A. 2004. Vegetation on Alpine rock glacier surfaces: a contribution to abundance and dynamics on extreme plant habitats. Flora 199: 505-515.

Burrows CJ. 1975. Late Pleistocene and Holocene moraines of the Cameron Valley, Arrowsmith Range, Canterbury, New Zealand. Arctic and Alpine Research 7: 125140.

Caseldine, CJ. 1990. A review of dating methods and their application in the development of a chronology of Holocene glacier variations in northern Iceland. In Gletscher und Landschaftsgeschichtliche Untersuchungen in Nordisland. Caseldine C, Häberle T, Kugelmann O, Münzer U, Stötter J, Wilhelm F. (eds). Münchener Geographische Abhandlungen B8: 59-82.

Caseldine, CJ 1991. Lichenometric dating, lichen population studies and Holocene glacial history in Tröllaskagi, Northern Iceland. In Environmental Change in Iceland: Past and Present: Maizels JK, Caseldine CJ (eds). Kluwer: Dordrecht; 219-233. 
Cook-Talbot JD. 1991. Sorted circles, relative-age dating and palaeoenvironmental reconstruction in an alpine periglacial environment, eastern Jotunheimen, Norway: lichenometric and weathering-based approaches. The Holocene 1: 128-141.

Dawson AG, Matthews JA, Shakesby RA. 1986. A catastrophic landslide (Sturzstrom) in Verkilsdalen, Rondane National Park, southern Norway. Geografiska Annaler 68A: 77-87.

Denton GH, Karlén W. 1973. Lichenometry: its application to Holocene moraine studies in southern Alaska and Swedish Lappland. Arctic and Alpine Research 5: 347-372.

Einarsson MA. 1991. Temperature conditions in Iceland 1901-1990. Jökull 41:1-42.

Erikstad L, Søllid JL. 1986. Neoglaciation in South Norway using lichenometric methods. Norsk Geografisk Tidsskrift 40: 85-103.

Evans DJA, Archer S, Wilson DJH. 1999. A comparison of the lichenometric and Schmidt hammer dating techniques based on data from the proglacial areas of some Icelandic glaciers. Quaternary Science Reviews 18: 13-41.

Follmann G. 1961. Estudios liquenometricos en los monumentos prehistoricos de la Isla de Pascua. Revista Universitaria - Anales de la Academia Chilena de Ciencias Naturales 24: 149-154.

Geirsdóttir A, Harðardóttir J, Andrews JT. 2000. Late-Holocene terrestrial glacial history of Miki and I.C. Jacobsen fjords, East Greenland. The Holocene 10: 123-134.

Gellatly AF. 1982. Lichenometry as a relative-age dating method in Mount Cook National Park, New Zealand. New Zealand Journal of Botany 20: 343-353.

Gob F, Petit F, Bravard J, Ozer A, Gob A. 2003. Lichenometric application to historical and subrecent dynamics and sediment transport of a Corsican stream (Figarella River-France). Quaternary Science Reviews 22: 2111-2124.

Goodwin ID. 1996. A mid to late Holocene readvance of the Law Dome ice margin, Budd Coast, East Antarctica. Antarctic Science 8: 395-406.

Gordon JE, Sharp M, 1983. Lichenometry in dating recent glacial landforms and deposits, southeast Iceland. Boreas 12: 191-200.

Haeberli W, King L, Flotron A. 1979. Surface movement and lichen-cover studies at the active rock glacier near the Grubengletscher, Wallis, Swiss Alps. Arctic and Alpine Research 11: 421-441.

Hausmann EH. 1948. Measurements of the annual growth rate of two species of rock lichens. Bulletin of the Torrey Botanical Club 75: 116-117. 
Haworth LA, Calkin PE, Ellis, JM. 1986. Direct measurmet of lichen growth in the Central Brooks Range, Alaska, USA, and its application to lichenometric dating. Arctic and Alpine Research 18: 289-296.

Hooker TN. 1980. Factors affecting the growth of Antarctic crustose lichens. British Antarctic Survey Bulletin 50: 1-19.

Innes JL. 1982. Debris flow activity in the Scottish Highlands. Unpublished PhD thesis, University of Cambridge: 557pp

Innes JL. 1983. Use of an aggregated Rhizocarpon 'species' in lichenometry: an assessment. Boreas 12: 183-190.

Innes JL. 1985. Lichenometry. Progress in Physical Geography 9: 187-254.

Innes JL. 1986. The size-frequency distributions of the lichens Sporastatia testudinea and Rhizocarpon alpicola through time at Storbreen, south-west Norway. Journal of Biogeography 13: 283-291.

Jonasson C, Kot M, Kotarba A. 1991. Lichenometrical studies and dating of debris flow deposits in the High Tatra Mountains, Poland. Geografiska Annaler 73A: 141146.

Karlén W. 1973. Holocene glacier and climatic variations, Kebnekaise mountains, Swedish Lapland. Geografiska Annaler 55A: 29-63.

Karlén W. 1979. Glacier fluctuations in the Svartisen area, northern Norway. Geografiska Annaler 61A, 11-28.

Karlén W, Black JL. 2002. Estimates of lichen-growth rate in northern Sweden. Geografiska Annaler 84A: 225-232.

Karlén W, Denton GH. 1975. Holocene glacial variations in Sarek National Park, northern Sweden. Boreas 5, 25-56.

Kershaw KA. 1985. Physiological Ecology of Lichens. Cambridge University Press: 293pp.

Kirkbride MJ, Dugmore AJ. 2001. Can lichenometry be used to date the 'Little Ice Age' glacial maximum in Iceland? Climatic Change 48: 151-167.

Kugelmann O. 1991. Dating recent glacier advances in the SvarfaðardalurSkiðadalur area of northern Iceland by means of a new lichen curve. In:

Environmental Change in Iceland: Past and Present, Maizels JK, Caseldine CJ (eds). Kluwer, Dordrecht: 219-233.

Larocque SJ, Smith DJ. 2004. Calibrated Rhizocarpon spp. growth curve for the Mount Waddington Area, British Columbia Coast Mountains, Canada. Arctic, Antarctic and Alpine Research 36: 407-418. 
Laundon JR. 1980. The use of lichens for dating walls in Bradgate Park, Leicestershire. Transactions of the Leicester Literary and Philosophical Society 74: $11-30$.

Lawrey JD, Hale ME. 1977. Natural history of Plummers Island, Maryland XXIII. Studies on lichen growth rate at Plummers Island, Maryland. Proceedings of the Biological Society of Washington 90: 698-725.

Locke WW, Andrews JT, Webber PJ. 1979. A manual for lichenometry. British Geomorphological Research Group, Technical Bulletin 26: 1-47.

Lowell, TV, Schoenenberger K, Dedens J, Denton G, Smith C, Black J, Hendy C. 2005. Rhizocarpon calibration curve for the Aoraki/Mount Cook area of New Zealand. Journal of Quaternary Science 20: 313-325.

Luckman BH. 1977. Lichenometric dating of Holocene moraines at Mount Edith Cavell, Jasper, Alberta. Canadian Journal of Earth Sciences 14: 1809-1822.

Maas GS, Macklin M. 2002. The impact of recent climate change on flooding and sediemtn supply within a Mediterranean catchment, southwestern Crete, Greece. Earth Surface Processes and Landforms 27: 1087-1105.

Macklin MG. 1986. Channel and Floodplain metamorphosis in the River Nent, Cumberland. In: Quaternary River Landforms and sediments in the Northern Pennines, England: Field Guide, Macklin MG, Rose J. (eds). British

Geomorphological Research Group / Quaternary Research Association: London; 1933.

Macklin MG, Rumsby BT, Heap T. 1993. Flood alluviation and entrenchment: Holocene valley floor development and transformation in the British Uplands. Geological Society of America Bulletin.

Maizels JK, Dugmore AJ. 1985. Lichenometric dating and tephrochronology of sandur deposits, Sólheimajökull area, southern Iceland. Jökull 35: 69-77.

Maizels JK, Petch JR. 1985. Age determination of inter-moraine areas, Austerdalen, southern Norway. Boreas 14: 51-65.

Martin HE, Whalley WB, Orr J, Caseldine C. 1994. Dating and interpretation of rock glaciers using lichenometry, south Tröllaskagi, north Iceland. In: Stötter, J and Wilhelm, F. Environmental change in Iceland. Münchener Geographische Abhandlungen B12: 205-224.

Matthews JA. 1974. Families of lichenometric dating curves from the Storbreen gletschervorfeld, Jotunheimen, Norway. Norsk geografisk Tidsskrift 28: 215-235.

Matthews JA. 1975. Experiments on the reproducibility and reliability of lichenometric dates, Storbreen gletschervorfeld, Jotunheimen, Norway. Norsk Geografisk Tidsskrift 29: 97-109. 
Matthews JA. 1977. A lichenometric test of the 1750 end-moraine hypothesis: Storbreen gletschervorfeld, southern Norway. Norsk geografisk Tidsskrift 31: 129136.

Matthews JA. 1994. Lichenometric dating: A review with particular reference to 'Little Ice Age' moraines in southern Norway. In Dating in Surface Contexts, Beck C (ed.) New Mexico University Press: 185-212.

Matthews JA. 2005. 'Little Ice Age' glacier variations in Jotunheimen, southern Norway: a study in regionally controlled lichenometric dating of recessional moraines with implications for climate change and lichen growth rates. The Holocene 15: 1-19.

Matthews JA, Dawson AG, Shakesby RA. 1986. Lake shoreline development, frost weathering and rock platform erosion in an alpine periglacial environment, Jotunheimen, Norway. Boreas 13: 333-400.

McCarroll D. 1994. A new approach to lichenometry: dating single-age and diachronous surfaces. The Holocene 4: 383-396.

McCarthy DP. 2003. Estimating lichenometric ages by direct and indirect measurement of radial growth: a case study of Rhizocarpon agg. at the Illecillewaet glacier, British Columbia. Arctic, Antarctic and Alpine Research 35: 202-213.

McKinzey K, Orwin J, Bradwell T. 2004. Re-dating the moraines at Heinabergsjökull and Skalafellsjökull: testing the lichenometric method. Geografiska Annaler 86A: 319-336.

Merrett SP, Macklin MG. 1999. Historic river response to extreme flooding in the Yorkshire Dales, northern England. In Fluvial Processes and Environmental Change, Brown AG, Quine TA (eds). Wiley: Chichester; 345-360.

Miller CD. 1969. Chronology of neoglacial moraines in the Dome Peak area, North Sawatch Range, Colorado. Arctic and Alpine Research 5: 385-400.

Miller GH, Andrews JT. 1972. Quaternary history of northern Cumberland Peninsula, East Baffin Island, Northwest Territory, Canada. Part VI: Preliminary lichen growth curve. Geological Society of America Bulletin 83: 1133-1138.

Mottershead DN, White ID. 1972. The lichenometric dating of glacier recession, Tunbergsdal, southern Norway. Geografiske Annaler 54A: 47-52.

Nikonov AA, 1988. Reconstruction of the main parameters of old large earthquakes in Soviet Central Asia using the paleoseismogeological method. Tectonophysics 147: 297-312.

Nikonov AA, Shebalina TY. 1979. Lichenometry and earthquake-age determination in Central Asia. Nature 280: 675-677. 
Noller JS, Locke WW. 2001. Lichenometry. In Quaternary Geochronology: Methods and Applications, Noller, JS et al. (eds). American Geophysical Union: Washington DC; 261-272.

O’Neal MA, Schoenenberger KR. 2003. A Rhizocarpon geographicum growth curve for the Cascade Range of Washington and northern Oregon, USA. Quaternary Research 60: 233-241.

Poelt J. 1988. Rhizocarpon Ram. em. Th. Fr. subgen. Rhizocarpon in Europe. Arctic and Alpine Research 20: 292-298.

Porter SC. 1981. Lichenometric studies in the Cascade Range of Washington: Establishment of Rhizocarpon geographicum growth curves at Mount Rainier. Arctic and Alpine Research 13: 11-23.

Porter SC, Orombelli G. 1981. Alpine rockfall hazards. American Scientist 69: 67-75.

Proctor MCF. 1983. Sizes and growth-rates of thalli of the lichen Rhizocarpon geographicum on the moraines of the Glacier de Valsorey, Valais, Switzerland. The Lichenologist 15: 249-261.

Purvis OW, Coppins BJ, Hawksworth DL, James PW, Moore DM. 1992. The Lichen Flora of Great Britian and Ireland. Natural Hiistory Museum Publications, London.

Rodbell DT. 1992. Snowline lowering in the Peruvian Andes. Boreas 21: 43-52.

Rogerson RJ, Evans, DJA, McCoy, WD. 1986. Five-year growth of rock lichens in a low-arctic mountain environment, Northern Labrador. Géographie physique et Quaternaire XL: 85-91.

Runemark H. 1956. Studies in Rhizocarpon II. Distribution and ecology of the yellow species in Europe. Opera Botanica 2: 1-150.

Rydzak, J. 1961. Investigations on the growth rate of lichens. Annales Universitatis Mariae Curie-Sklodowska, Section C [Lublin] 16: 1-15.

Sancho LG, Pintado A. 2004. Evidence of high annual growth rate for lichens in the maritime Antarctic. Polar Biology 27: 312-319.

Sancho LG, Valadares F. 1993. Lichen colonization of recent moraines on Livingston Island (South Shetland Island, Antarctica). Polar Biology 13: 227-233.

Shakesby RA, Dawson AG, Matthews JA. 1987. Rock glaciers, protalus ramparts and related phenomena, Rondane, Norway: A continuum of large-scale talus-derived landforms. Boreas 16: 305-317.

Smirnova TT, Nikonov AA. 1990. A revised lichenometric method and its application: dating great past earthquakes. Arctic and Alpine Research 22:375-388. 
Smith DJ, McCarthy DP, Colenutt ME. 1995. Little Ice Age glacial activity in Peter Lougheed and Elk Lakes Provincial Parks, Canadian Rocky Mountains. Canadian Journal of Earth Sciences 32: 579-589.

Solomina O, Calkin PE. 2003. Lichenometry as applied to moraines in Alaska, USA, and Kamchatka, Russia. Arctic, Antarctic and Alpine Research 35: 129-143.

Spence JR, Mahaney WC. 1988. Growth and ecology of Rhizocarpon section Rhizocarpon on Mount Kenya, East Africa. Arctic and Alpine Research 20: 237-242.

Ten Brink NW. 1973. Lichen growth rates in West Greenland. Arctic and Alpine Research 5: 323-331.

Thompson A. 1988. Historical development of the proglacial landforms of Svinafellsjökull and Skaftafellsjökull, southeast Iceland. Jökull 38: 17-31.

Thompson A, Jones A. 1986. Rates and causes of proglacial river terrace formation in southeast Iceland: An application of lichenometric dating techniques. Boreas 15: 231-246.

Vere D, Matthews JA. 1985. Rock glacier formation from a lateral moraine at Bukkeholsbreen, Jotunheimen, Norway: A sedimentological approach. Zeitschrift für geomorphologie NF 29: 397-415.

Werner A. 1990. Lichen growth rates for the northwest coast of Spitsbergen, Svalbard. Arctic and Alpine Research 22: 129-140.

Winchester V. 1984. A proposal for a new approach to lichenometry. British Geomorphological Research Group, Technical Bulletin 33:3-20.

Winchester V. 1988. An assessment of lichenometry as a method for dating recent stone movements in two stone circles in Cumbria and Oxfordshire. Botanical Journal of the Linnean Society 96: 57-68.

Winchester V, Chaujar RK. 2002. Lichenomtric dating of slope movements, Nant Ffrancon, North Wales. Geomorphology 47:61-74.

Winchester V, Harrison S. 1994. A development of the lichenometric method applied to dating of glacially influenced debris flows in southern Chile. Earth Surface Processes and Landforms 19: 137-151.

Winchester V, Harrison, S. 2000. Dendrochronology and lichenometry: colonization, growth rates and dating of geomorphological events on the east side of the North Patagonian Icefield, Chile. Geomorphology 34:181-194.

Winchester V, Harrison S, Warren CR. 2001. Recent retreat of Glacier Nef, Chilean Patagonia dated by lichenometry and dendrochronology. Arctic, Antarctic and Alpine Research 33: 266-273. 
Winkler S. 2000. The 'Little Ice Age' maximum in the Southern Alps, New Zealand: preliminary results at Mueller Glacier. The Holocene 10: 643-647.

Winkler S, Matthews JA, Shakesby R, Dresser Q. 2003. Glacier variations in Breheimen, southern Norway: dating Little Ice Age moraine sequences at seven lowaltitude glaciers. Journal of Quaternary Science 18: 359-413. 


\section{Figure captions}

Figure 1: A. Location map of the study site in Southern Iceland. B. Climatic setting of the study site at Gigjökull (G). Shaded values show mean annual precipitation (1960-1990); dashed lines show mean annual air temperature isotherms $\left({ }^{\circ} \mathrm{C}\right)(1960-1990)$ (Einarsson, 1991). Ice caps: $\mathrm{M}=$ Myrdalsjökull; $\mathrm{E}=$ Eyjafjallajökull. Central volcanoes shown as triangles. C. Detailed map of the study site at Gigjökull showing the location of lichen measurements stations (1) and (2). D. Photograph of the moraines at Gigjökull in September 2005 (taken from x on map C). Note that the ice margin has receded c. $1.5 \mathrm{~km}$ since 1996.

Figure 2: A. Photographs of Rhizocarpon geographicum thalli (GIG31 \& GIG33) measured in this study (taken in September 2005). The paint marks around the edge were made in 2001 as reference points. B. The outline of the thallus traced from photographs taken in May 2001 and September 2005. Measurement axes are also shown. Note the change in diameter over the intervening period (c. 4-6 mm).

Figure 3: Diametral growth rate of Rhizocarpon geographicum (mm/yr) plotted against lichen diameter (mm in 2001), from Gigjökull, southern Iceland.

Figure 4: Comparison of diametral growth rates of Rhizocarpon geographicum from Armstrong (1983) (grey dots) and this study (black dots). (Armstrong's (1983) radial growth rate data have been converted to DGR (ie. multiplied by 2) and scaled to mm/12 months for direct comparison with this study).

Figure 5: Growth-rate curves of R. geographicum from different climates. (1) South Island, New Zealand (hypothesised); (2) north Wales (Armstrong, 1983); (3) south Iceland (this study); (4) north Iceland (hypothesised); (5) west Greenland, 68º $\mathrm{N}$ (hypothesised). Letters denote phases of lichen growth - a: establishment; b: juvenile; c: maturation; d: maturity or senescense. DGR - diametral growth rate.

Table 1: Some worldwide applications of lichenometric dating. 

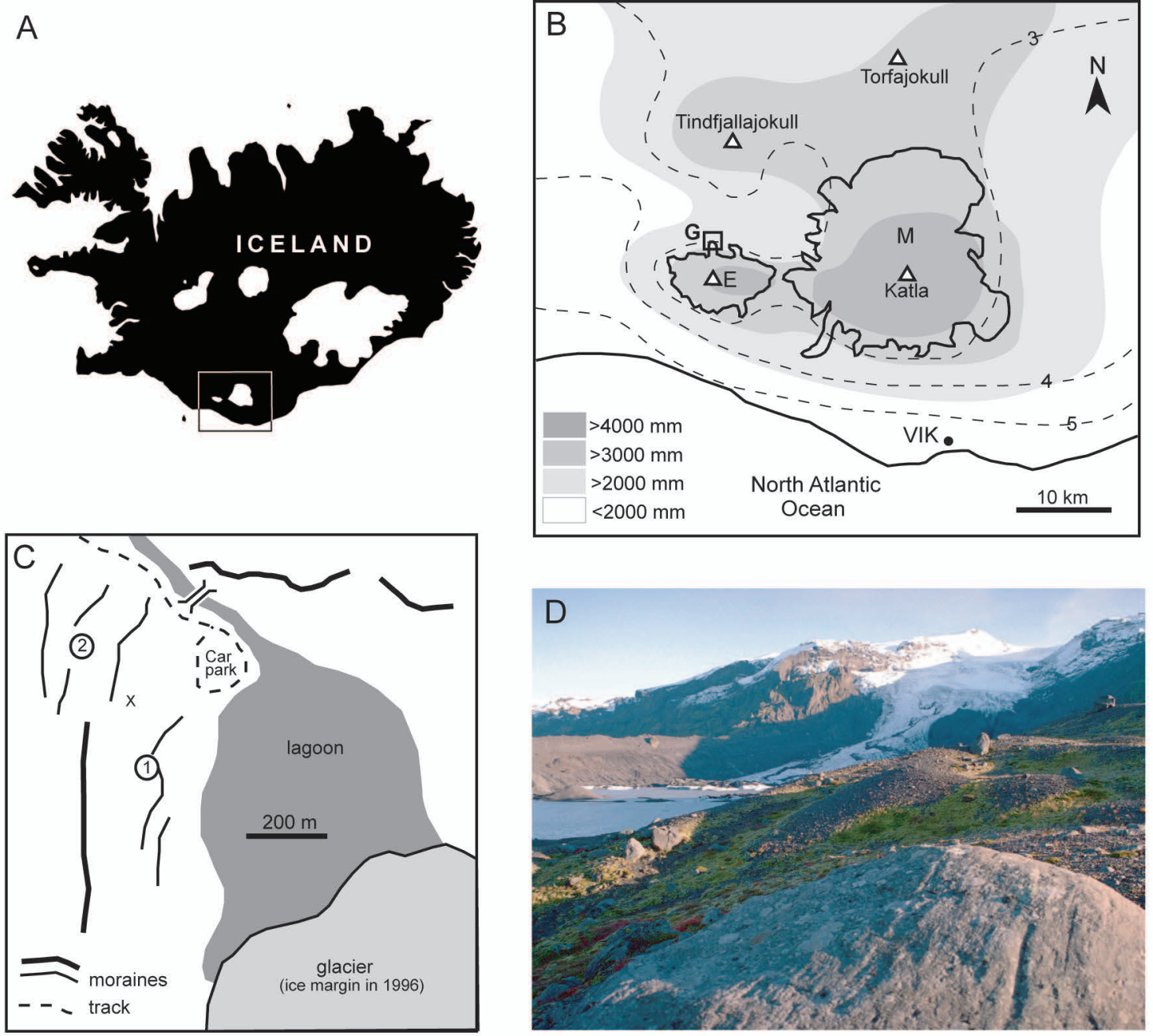

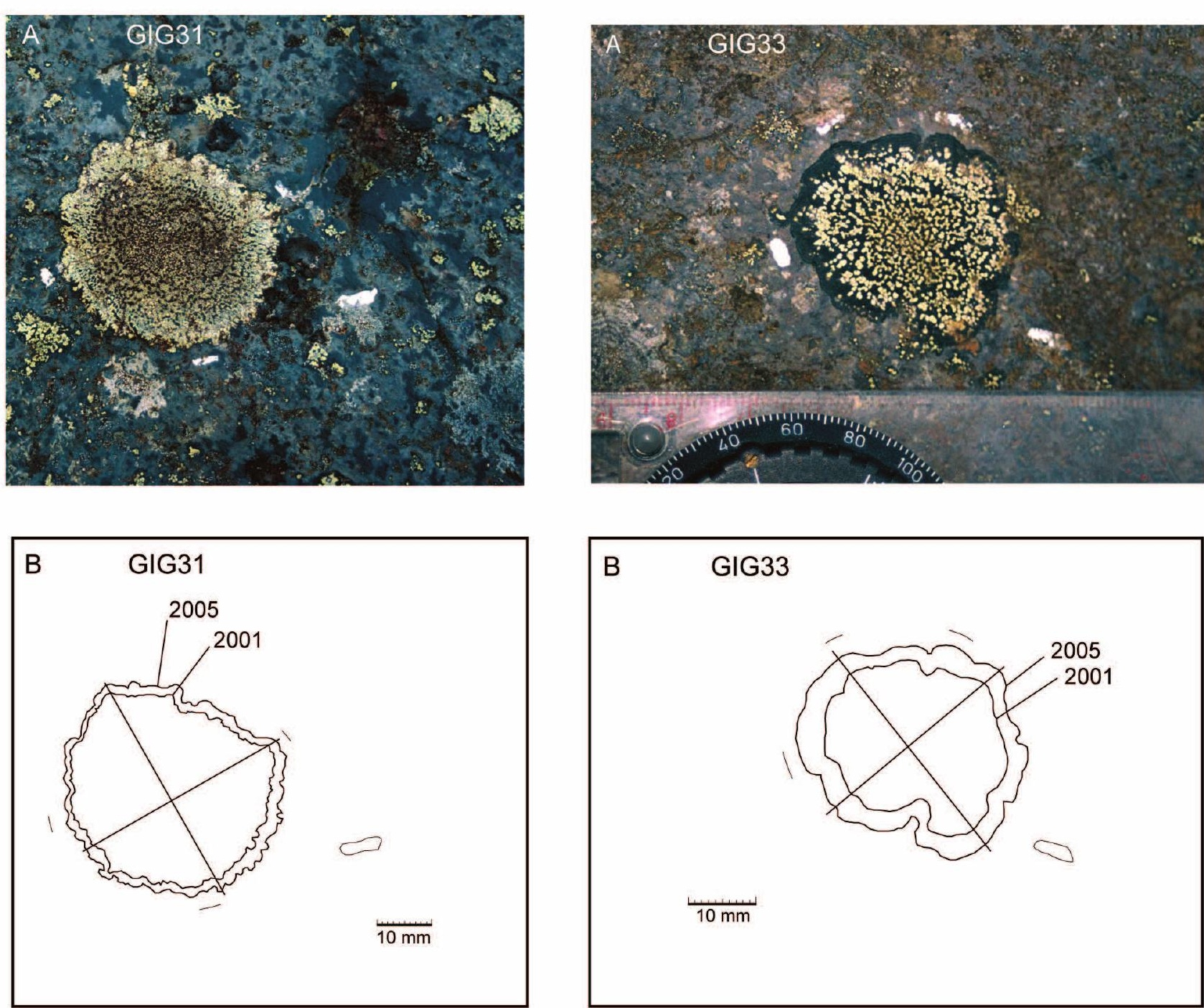


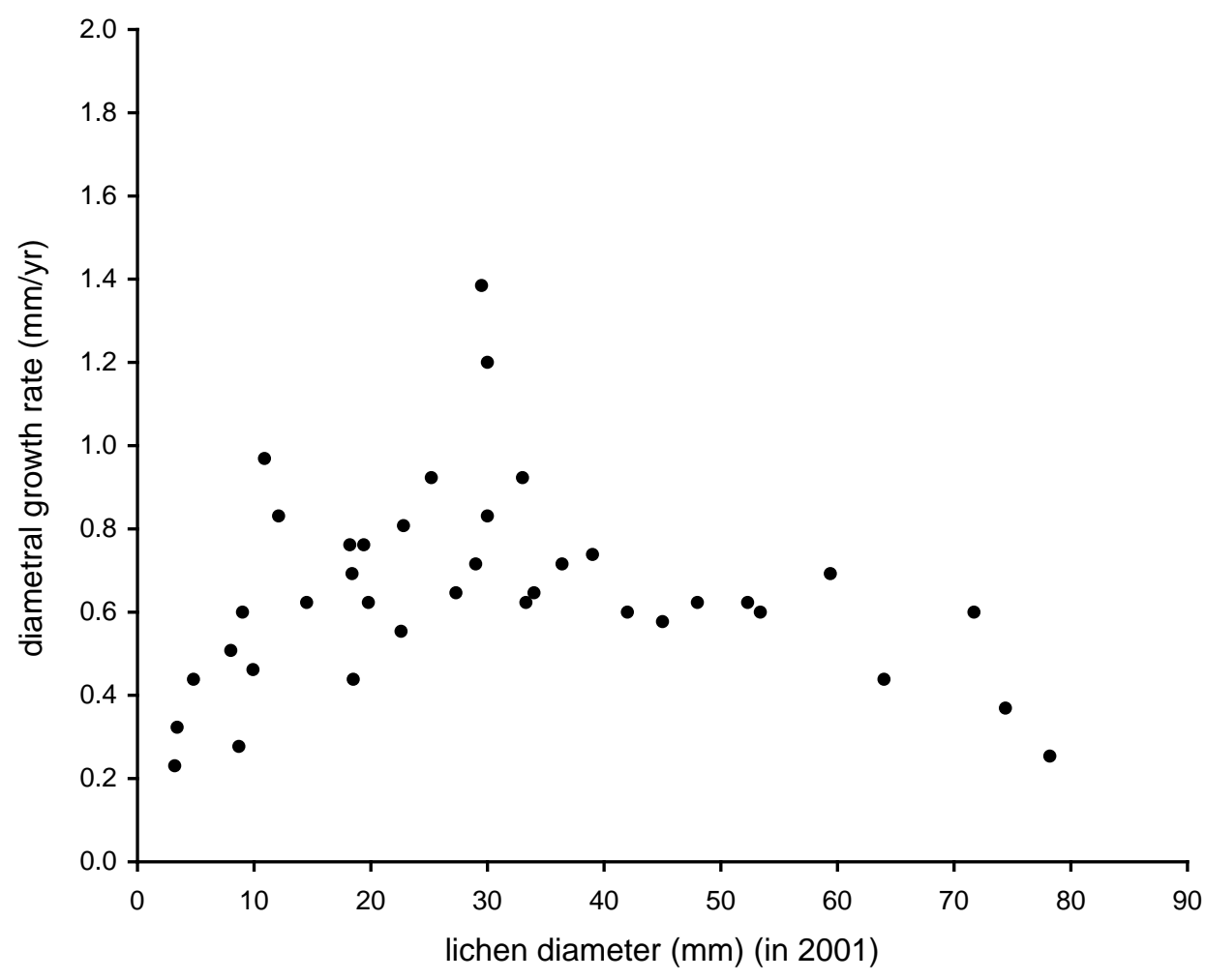




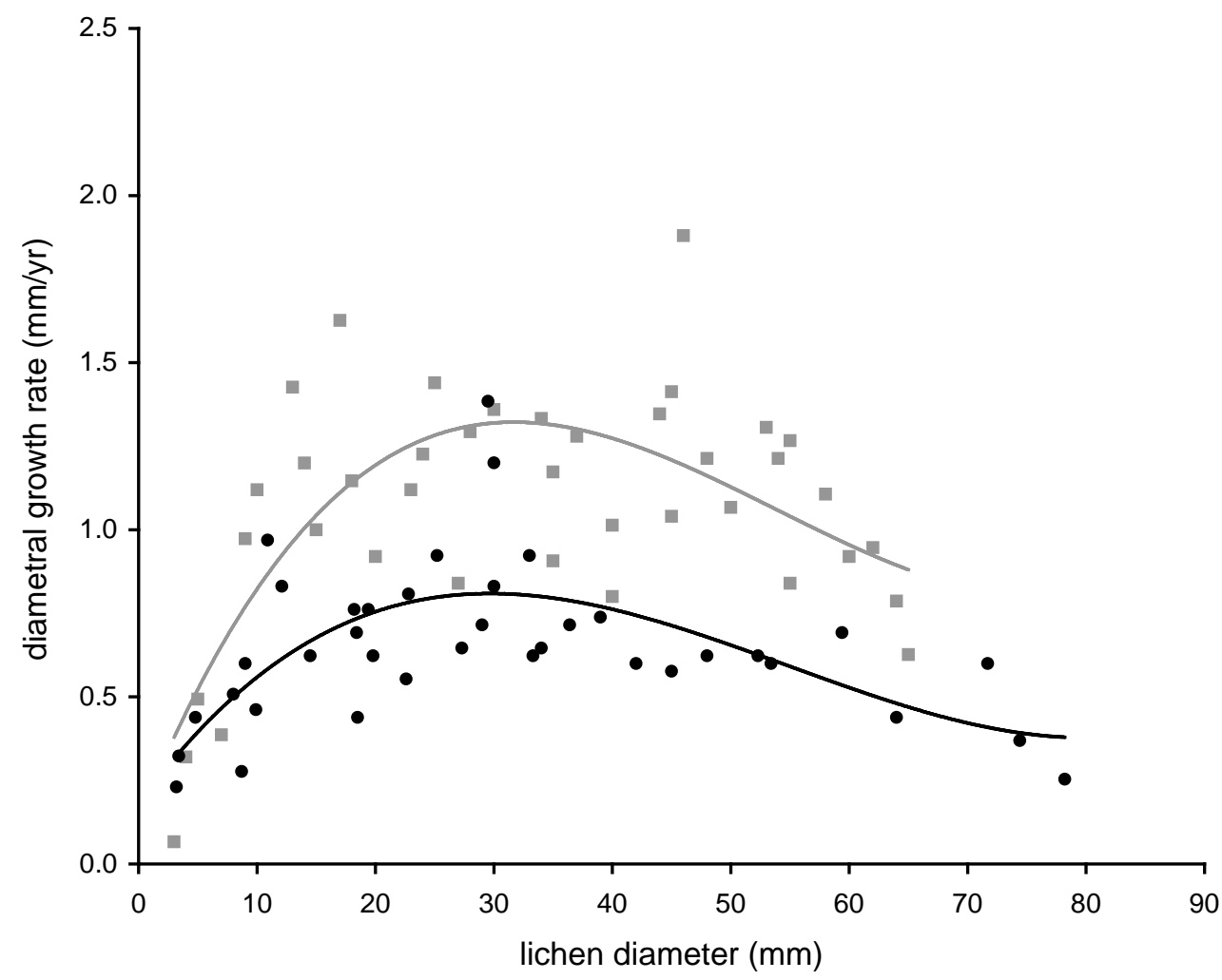




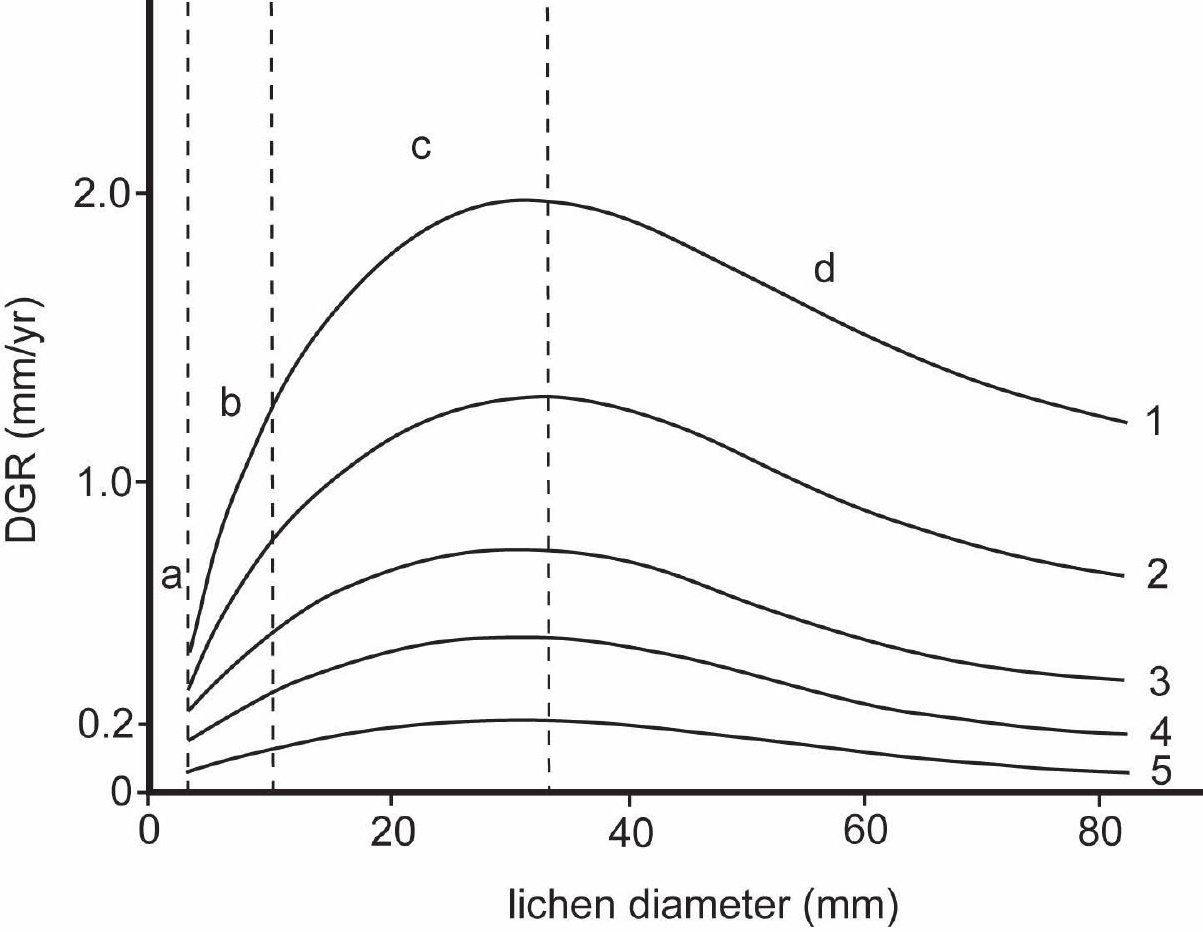


Type of surface Location Author(s)

\begin{tabular}{|c|c|c|c|c|c|}
\hline Type of surface & Location & Author(s) & & & \\
\hline River channels (abandoned) & England & $\begin{array}{l}\text { Macklin (1986); } \\
\text { Macklin et al. (1993) }\end{array}$ & $\begin{array}{l}\text { Earthquake-induced } \\
\text { faults/disruptions }\end{array}$ & Tadjikistan & $\begin{array}{l}\text { Nikonov and Shebalina (1979); Smirnova and } \\
\text { Nikonov (1990); }\end{array}$ \\
\hline \multirow[t]{4}{*}{ River terraces } & England & Merrett and Macklin (1999) & & California & Bull (1996) \\
\hline & Iceland & Maizels and Dugmore (1985); & Earthquake-induced & Russia & Nikonov (1988) \\
\hline & & Thompson and Jones (1986) & rockfalls & New Zealand & Bull et al. (1994); Bull and Brandon (1998) \\
\hline & Norway & Maizels and Petch (1985) & Snow-free areas & Colorado & Benedict (1993) \\
\hline \multirow[t]{2}{*}{ Flood deposits } & Greece & Maas \& Macklin (2002) & Moraines & Iceland & Thompson (1988); Evans et al. (1999); \\
\hline & Corsica & Gob et al. (2003) & & & Caseldine (1990, 1991); Kugelmann (1991) \\
\hline \multirow[t]{3}{*}{ Lake shorelines } & Norway & Matthews et al. (1986) & & & Bradwell (2004); Bradwell et al. (2006) \\
\hline & Spitsbergen & Andre $(1985,1986)$ & & & McKinzey et al. (2004) \\
\hline & Iceland & Evans et al. (1999) & & Norway & Denton and Karlen (1973); \\
\hline Raised beaches & Gulf of Bothnia & Broadbent and Bergqvist (1986) & & & Matthews $(1974,1977,1994,2005)$ \\
\hline \multirow[t]{4}{*}{ Rock glaciers } & Norway & Vere and Matthews (1985) & & & Innes (1986); Erikstad and Sollid (1986); \\
\hline & Iceland & Martin et al. (1994) & & & McCarroll (1994); Ballantyne (1990); \\
\hline & Swiss Alps & Haeberli et al. (1979); & & & Bickerton and Matthews (1992); Winkler et al. (2003) \\
\hline & & Burga et al. (2004) & & Spitsbergen & Werner (1990) \\
\hline Protalus ramparts & Norway & Shakesby et al. (1987) & & Greenland & Beschel $(1958,1961)$; Geirsdottir et al. (2000) \\
\hline Patterned ground & Norway & Cook-Talbot (1991) & & Alaska & Denton and Karlen (1973); Solomina and Calkin (2003) \\
\hline Talus & Spitsbergen & Andre $(1985,1986)$ & & Canada & Luckmann (1977); Smith et al. (1995) \\
\hline \multirow[t]{2}{*}{ Debris flows } & Scotland & Innes (1982) & & & Larocque and Smith (2004) \\
\hline & Poland & Jonasson et al. (1991) & & Patagonia & Winchester and Harrison $(1994,2000)$ \\
\hline \multirow[t]{2}{*}{ Landslides } & Italian Alps & Porter and Orombelli (1981) & & & Winchester et al. (2001) \\
\hline & Norway & Dawson et al. (1986) & & New Zealand & Burrows (1975); Gellatly (1982) \\
\hline Statues & Easter Island & Follmann (1961) & & & Winkler (2000); Lowell et al. (2005) \\
\hline \multirow[t]{2}{*}{ Stone walls } & England & Laundon (1980) & & Kenya & Spence and Mahaney (1988) \\
\hline & Colorado & Benedict (1985) & & Peru & Rodbell (1992) \\
\hline Stone circles & England & Winchester $(1984,1988)$ & & Antarctica & Sancho and Valadares (1993); Goodwin (1996) \\
\hline
\end{tabular}

